\title{
Bir mecmuadan hareketle Edirneli şâirlerin şiirleri
}

\section{Orhan KILIÇARSLAN}

APA: Kılıçarslan, O. (2019). Bir mecmuadan hareketle Edirneli şâirlerin şiirleri. RumeliDE Dil ve Edebiyat Arassturmaları Dergisi, (17), 167-190. DOI: 10.2900o/rumelide.656676

\section{$\ddot{\mathbf{O} z}$}

Edebiyat tarihinde uzun bir dönemi kapsayan klasik edebiyat içinde döneminin edebî görünümünü, eğilimlerini, şairler arasındaki ilişkileri gösteren mecmualar, bazı örneklerde mecmua derleyicileri tarafından müşterek bir özellik esas alınarak oluşturulmuştur. Ortak bir mevzu etrafında meydana getirilen mecmualar içerisinde bir coğrafyaya has şairlerin şiirlerinin derlendiği örnekler de mevcuttur. Bu durum, söz konusu saha veya bu sahadaki üsluplar üzerine genel bir değerlendirmeyi tarihî olarak sunması bakımından değerlidir. Edirne Selimiye Yazma Eser Kütüphanesi’nde 22 Sel 2299 numarada kayıtlı olan mecmua, Edirneli şairler ve onların Türkçe şiirlerini derlemesi yönüyle ortak bir özellik etrafında derlenen mecmualar sınıfındadır. Mecmuada tamamı Edirneli/Edirnevî olarak kaydedilen 84 şairin bir kısmının Edirneli olmadı̆̆ı; ancak Edirne ile bir vesile ile ilişkilı olduğu görülmektedir. Bu kayıtlarda edebiyat tarihinin temel kaynakları olan tezkirelerde kaydedilen bilgilerin etkisi olduğu söylenebilir. Mecmuada şiirleri yer alan bu şairlerin çoğunluğunun divan olduğu kayıtlı ise de bir kısmı bugün elde mevcut değildir. Bu çalışmada mecmuada şiirleri kaydedilen şairlerin şiirlerinin tespiti noktasında bilinen divanları yanında Edirne şairlerini, Edirne tarihini anlatan eserler de incelenerek daha önce herhangi bir kaynakta bulunmayan şiirleri gösterilmeye çalışılmıştır.

Anahtar kelimeler: Klasik edebiyat, mecmua, Edirne, şiir.

\section{Poems by poets of Edirne with reference to a macmuah}

\section{Abstract}

Macmuahs that show the relationship among poets, the literary view and tendencies of the classical literature of that period which covers a long period in literature history, in some examples were created based on a collective characteristic by magazine compilers. In macmuahs which have been constituted around a common subject, examples exist where poems by poets who unique to one geography have been compiled. This situation is valuable in terms of presenting a general view on aforementioned area or styles in that area as historical. Macmuah that is registered with archive number 22 Sel 2299 at the Edirne Selimiye Manuscript Library is in the macmuah category in which macmuahs have been compiled around the common characteristics because of poets of Edirne compiling their Turkish poems. It can be seen that some of the 84 poets that were registered in macmuah as Edirnevî/Edirneli were not from Edirne; however they had somewhat relations to tie them to Edirne. It can be said that the information recorded on biographies, which is the primary resource of literature history had an effect on these records. Although it is recorded that majority of the poets whose poems were in macmuah had dewan, today some of them are not available. In this study, an attempt were made to show the poems that can't be found in any source by poets whose

1 Dr. Öğr. Üyesi, Düzce Üniversitesi, Fen Edebiyat Fakültesi, Türk Dili ve Edebiyatı Bölümü (Düzce, Türkiye), orhankilicarslan@duzce.edu.tr, ORCID ID: 0000-0001-9479-6975 [Makale kaylt tarihi: 28.10.2019-kabul tarihi: 20.12.2019; DOI: 10.29000/rumelide.656676] 
168 / RumeliDE Journal of Language and Literature Studies 2019.17 (December)

Poems by poets of Edirne with reference to a macmuah / O. Kilıçarslan (pp. 167-190)

poems recorded in macmuah beside their known dewan by analyzing the works that describes history and poets of Edirne.

Keywords: Classical litearature, macmuah, Edirne, poem.

\section{Giriş}

Şiir mecmuaları, klasik edebiyat geleneği içerisinde şairlerin kendilerinin topladıkları yahut da başka şahıslar tarafından derlenen/tertip edilen divanları dışında edebiyat tarihi açısından ikinci derece öneme sahip kaynaklardır. Mecmua kelimesi, "dağımık şeyleri bir araya getirmek, biriktirmek" (Erkan 2012:942) anlamında Arapça cem" masdarından "içinde şïrler, seçilmiş söz ve yazılar bulunan el yazmasl kitap; koleksiyon" (Ayverdi 2005:1972) anlamında terim olarak manzum/mensur metinlerin toplandı̆̆ı eserler için kullanılan bir ifadedir. Mecmualar yalnızca şiir metinlerinin bir araya getirildiği defterler olmayıp mensur olarak muhtelif konularda yazılmış eserlerin derlenmesiyle de meydana getirilmiştir. Cem edilmiş, toplanmış anlamından hareketle mecmualarda farklı şairlerin şiirleri olduğu gibi edebî, dînî vb. farklı konuları ihtiva eden mensur mecmualar da vardır. Şiir mecmuaları arasında edebiyat tarihi açısından özel bir yere sahip olan nazire mecmuaları geleneğin takip çizgisini, eğilimlerini, edebi metinlerin dil vasıtasıyla rağbet ve dönüşümlerini göstermesi bakımından önemlidir. Mevcut bilgilere göre ilk örneğini 15. yüzyılda Ömer bin Mezîd'in Mecmu'atü’n-Nezẩir'i ile veren nazire mecmuaları, sonraki yüzyıllarda farklı şahıslar eliyle sistematik bir biçimde oluşturulmuştur. ${ }^{2}$ Zaman içerisinde nazire mecmualarının yerini -önceki yüzyıllarda da örnekleri görülmesi yanında- bireysel tercihlerin, beğenilerin öne alındığı mecmualar almıştır. Belli zümreden olan şairlerin şiirleri, -edebiyat geleneği içerisinde belli oranda uygulanan- bir tarikat/mezhep büyüğüne yazılan şiirlerin derlendiği mecmualar yanında belli bir coğrafyaya, şehre ait şairlerin şiirlerinin derlendiği mecmualar da görülmektedir.

Edebiyat tarihi açısından temel biyografik kaynaklar olan tezkirelerdeki bilgi kısmı dışında doğrudan şairlerin şiirlerinin kaydedildiği ve özellikle unvan/başlıklarda verilen kısa bilgilerle meydana getirilen mecmualar özel/sınıflandırılmış mecmualar kategorisinde değerlendirilebilir. Bu özellikleri haiz mecmualar yapı itibariyle antoloji tarzı tezkirelerle benzerlik göstermektedir. Bu tarz mecmuaların derleyicisi, belirli olan alanda derlemesini yapacağından mecmua tasnifine özel bir araştırma ve ilgi ile yaklaşacaktır. Bu ilgi ve araştırma beklentisi, derleyiciyi belirli, bilinen kaynaklara yönlendireceğinden mecmualarda yer verilen şair ve şiirleri ile edebiyat tarihine ait kaynaklardaki tanıklar örtüşecektir. Mecmualarda verilen örneklerde belli başlı kaynaklarda kayıtlı müellif-metin uyuşmazlı̆̆ının olması durumu, derleyicinin bu kaynaklar dışında ya da başka vasıtalar kullanarak derlemesini yaptığını göstermektetir. Bu durumda mecmuada kaydedilmiş şiirlerin şairinin kim olduğuna ilişkin tespit güçleşecektir. Bunun yanında mecmuada kaydedilen şiirlerin tespit edilen şairin dönemini kapsayan nazire mecmuaları, tezkireler yahut diğer edebiyat kaynaklarında bulunmaması da bu mecmuanın değerini artıracaktır.

Mecmuaların içeriği, kapsamı veya herhangi ortak bir özellik etrafında şekillenip şekillenmediğine ilişkin tespitler, kaydedilen şiirlerden hemen önce verilen bilgilerden elde edilebilir. Nazire mecmualarında zemin şiirlerin ve sonrasında gelen nazire şiirlerin belli kalıplarda ifade edilmesine

\footnotetext{
Nazire mecmuaları ile ilgili geniş bilgi için bkz. M. Fatih Köksal. (2006). Sana Benzer Güzel Olmaz. Divan Şiirinde Nazire. Akçağ Yayınları. Ankara: 65-76. 
benzer şekilde bu tarz mecmualarda da şiirin kime ait olduğuna, şiirin nazım şekline yahut diğer bilgilere ulaşmak mümkündür.

Edirne Selimiye Yazma Eser Kütüphanesi 22 Sel 2299 numarada Mecmua-i Eş’ar ve Münşeat adıyla kayıtlı mecmua bu özellikleri havi bir mecmua olarak dikkat çekmektedir. Mecmuada şiirleri kaydedilen şairlerle ilgili olarak "Edirneli/Edirnevî" ibaresi her şairin ismi önünde/sonunda belirtilmiştir. Bazı kayıtlarda bu ibareden sonra şairin ismine, lakabına ilişkin "Edirneli Nutkî Karakaş-zâde Pîr Muhammed Çelebi", "Nişânî Mehmed Paşa Edirnevî Üsküfçü Hızır Mahallesinde medfûndur" biçiminde açıklamalar verilmiştir. Bazı şairlerin kaydedilen şiirlerinin nazım şekillerine dair "muaşşerden müfrez beyt" gibi açılayıcı bilgiler de görülmektedir. Mecmuanın geneli mensur metinlerden oluşmaktadır. Birkaç varakta sistemli bir biçimde kaydedilen şiir metinleri çoğunlukla bu mensur metinlerin üst kısımlarına yazılmıştır. Bu kayıtlar mensur metinlerin aksi yönünde mecmua ters çevrilerek kaydedilmiştir. Mecmuanın varak numaraları düzensiz olup iki ayrı numaralandırma yapılmıştır. Bu durum mecmuanın iki farklı şekilde düşünülüp iki ayrı numaralandırmaya gidilmesinden yahut da elde olan mecmuanın içeriğinden hareketle bir bütünlük arz etmesi amacıyla aynı esere kaydedilmesinden kaynaklanmış olabilir. Mecmuada manzum kısımlarda varak yüzleri, bir sayfanın a/b yüzleri olarak değil tek yüz tek sayfa numarası olarak verilmiştir. Ayrıca mecmuada manzum kısmın varak numaraları sondan başa olacak biçimde düzenlenmiştir. Bu durum manzum kısımların mecmuaya ikinci sırada yani sonradan eklendiğini göstermektedir.

Mecmua, Edirneli şairlerin şiirlerini kaydetmek amacıyla derlenmiştir ve mecmuadaki -özellikle başlıklarda- bazı biyografik bilgiler, şiirlerin belli kaynaklardan derlendiği izlenimini uyandırmaktadır. Mecmuada Avnî mahlası ile şiirler yazan Fatih Sultan Mehmed'in şiirlerinin kaydedildiği varakta Avnî ile ilgili olarak "Ebu'l-feth Sultân Muhammed Hân-ı Gâzî kim mahlas-ı şerîfleri Avnîdür. Anun hükemât-ı belâgat-simâtındandır. Ol Ebû' '-feth ve'l-magâaînün Avnîdür mahlas-ı serîfleri. Bu ebyât Latîfi Tezkiresinde Sultân Bâyezîd-i Velî nâmmadur" (v. 25) şeklinde bir not düşülerek Latîfî Tezkiresi'ndeki bir bilgiye göndermede bulunulmuştur. Benzer şekilde Cevrî ve Cevherî mahlasl şairlerle ilgili olarak ise kaydedilen şiirin aidiyeti konusunda "Cevherî Karaferyeli İbn-i Yemîn Çelebi imiş âhiren tahkîk olundı Harrât-zâde Cevrî imiş” (v. 32) biçiminde düzeltme notu düşülmüştür.

Edirneli şairlerin şiirlerinin derlendiği mecmuada 84 şair kayıtlıdır. Bu şairlerin mahlasları ve mesleklerine ilişkin bilgiler şu şekildedir;

\begin{tabular}{|l|l|l|l|}
\hline İsim/Mahlas & Meslek $^{3}$ & İsim/Mahlas & Meslek \\
\hline Ahdî & Dîvân Kâtibi & Misâlî & Kâtip \\
\hline Ahmed Neşâtî & Mevlevî Şeyhi & Mehmed Cemaleddin & Uşşâkî Şeyhi \\
\hline Ali Gâlib & Şeyh, Müderris & Mehmed Hamdî & Uşşâkî Şeyhi \\
\hline Ali Seyfî & Dersiam & Muînî & Kadı̀ \\
\hline Askerî & Zeâmet sahibi & Müsellem & Gülşenî Şeyhi \\
\hline Atâ & Tabîb & Nazînâ & Kâtip, Hattât \\
\hline Attar-zâde Sânî & Tabîb ${ }^{4}$ & Nazmî & Silahdâr \\
\hline Avnî̀ & Padişah & Necâtî Sunîsi & - \\
\hline
\end{tabular}

3 Şairlerin mesleklerine ilişkin bilgiler, "Niyazi Adıüzel-Raşit Gündoğdu. (2014). Ahmed Bâdî Efendi Riyâz-1 Belde-i Edirne 20. Yüzylla Kadar Osmanlı Edirne'si” adlı çalışmadan ve Türk Edebiyatı İsimler Sözlüğü I'den (TĖ̇ I) alınmıștır. Aksoyak, İ.H. (2014). Sâniî, Attarzâde Mehmed Sâniî Çelebi (d./-ö.993/1585).

http://www.turkedebiyatiisimlersozlugu.com/index.php?sayfa=detay\&detay=3591 (e.t. 09.09.2019).

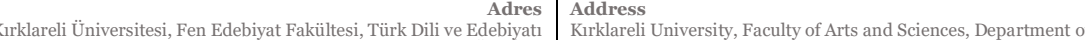
Bölümï, Kayalı Kampïsü-Kırklareli/TÜRKIYE Turkish Language and Literature, Kayalı Campus-Kırklareli/TURKEY e-posta: editor@rumelide.com 1 e-mail: editor@rumelide.com 
170 / RumeliDE Journal of Language and Literature Studies 2019.17 (December) Poems by poets of Edirne with reference to a macmuah / O. Kilıçarslan (pp. 167-190)

\begin{tabular}{|c|c|c|c|}
\hline Cevherî & Müderris & Necîb & Müderris \\
\hline Cevrî & Kadı & Nihâlî Çelebi & - \\
\hline Dâî & Hatip, Hâce & Nihânî & - \\
\hline Dânişî & - & Nişânî Mehmed Paşa & Nişancı \\
\hline Debbağ-zâde Şuâî & Yeniçeri & Nutkî & Kadı \\
\hline Dervîş Çelebi & - & Nühüft & Kâtip \\
\hline Emrî & Mütevellî & Ömer Seyrî & Arzuhalci \\
\hline Enîs Dede & Mevlevî Şeyhi & Örfi Ağa & Hattât \\
\hline Fâik Efendi & - & Rahşî Hâfız Ahmed & Kâtip \\
\hline Fazlî & Sanatkâr? 5 & Râzî & Kadı? \\
\hline Fedâyî & Sipâhî & Refî̀ & Kâtip ${ }^{7}$ \\
\hline Fitrî & Müderris, Hattat & Refîkî & Mütevellî \\
\hline Haffâf/Haffî & Sanatkâr (Haffâf) & Rızâ & Müderris, Kadı \\
\hline Hâfız Râzî (Çırpanlı hafiz) & Kâtip & Rifatî Çelebi & Kadı \\
\hline Hafîdî & - & Rindî & Gülşenî Dervişi \\
\hline Hâkimî & Kadı & $\begin{array}{l}\text { Rüşdî (Cerîde Nâzırı Hacı } \\
\text { Ahmed) }\end{array}$ & Kadı, Hattât \\
\hline Halîl Feyzî & Karantina emaneti & Sabrî bin İlmî-i Nâzik & Kadı \\
\hline Hasan Sezâyî & Gülşenî Şeyhi & Sâdık Bey & Hattât $^{8}$ \\
\hline Hâtemî & Sipâhî & Saîdî & Kadı \\
\hline Hâtifî & Mülâzım & Sâlikî & Nakkâş̧9 \\
\hline Hayâlî Abdî Çavuş & Asker/Çavuş & Sifâtî & Cerrâh \\
\hline Hayâlî Bey & Sancak Beyi ${ }^{10}$ & Şâdî & Asker \\
\hline Hıfzî & Müderris & Şerîf/Şerîfî & - \\
\hline Hulûsî & Hassa Hizmetlisi & Şevkî & Dîvân Kâtibi \\
\hline
\end{tabular}

5 Ahmed Bâdînnin Riyâz-1 Belde-i Edirne'sinde Fazlî mahlaslı iki şair vardır. Mecmuada kayıtlı şiirin Fazlî-i Leng ve Fazlî-i Dîger biçiminde kaydedilen bu iki Fazlî’den hangisine ait olduğu tespit edilemedi.

6 Ahmed Bâd’̂nnin Riyâz-ı Belde-i Edirne’sinde Râzî Muhyiddin, Râzî Mustafa (Çırpanlı Hafiz) ve Râzî Mehmet (Haydarzâde/Paydar-zâde) mahlaslı üç şair bulunmaktadır. Bunlardan Paydar-zâde lakabıyla tanınan Mehmed Râzî Efendi, "Düzenli bir öğrenim görmüş, pek çok yerde kadllık ve müderrislik yapmıştır. Râzî, Karaferye kadısı iken 1105/1693-94 yllinda vefat etmiştir."

Aksoyak, I. H. (2014). RÂZî, Paydarzâde/Haydarzâde Mehmed Râzî Efendi (d.?/?-ö.1105/1693-94).

http://www.turkedebiyatiisimlersozlugu.com/index.php?sayfa=detay\&detay=1463 (e.t. 09.09.2019).

Refiî mahlaslı șairin ayrıntılı biyografisi ve karșlastırma için bkz

Tanyıldız, A. (2014). Refî̀ (Refîkî), Amasyalı A’mẩ Refîî (Refíkî)(d.?/?-ö.939/1533).

http://www.turkedebiyatiisimlersozlugu.com/index.php?sayfa=detay\&detay=4826 (e.t. 10.09.2019).

Köksal, M. F. (2013). Refîkî (d.?/?-ö.939/1533/34)

http://www.turkedebiyatiisimlersozlugu.com/index.php?sayfa=detay\&detay=327 (e.t. 10.09.2019).

8 Şairin ayrıntılı biyografisi için bkz. Arif, Sunal (2014). Sâdık Dîvânı (İnceleme-Metin). Uludağ Üniversitesi SBE. Doktora Tezi. Bursa.

9 Ahmed Bâdî’nin Riyâz-ı Belde-i Edirne'sinde Sâlikî mahlaslı iki şairin biyografisi için bkz. Niyazi Adıgüzel-Rașit Gündoğdu. (2014). Ahmed Bâdî Efendi Riyâz-ı Belde-i Edirne 20. Yüzylla Kadar Osmanlı Edirne’si. Trakya Üniversitesi Yay. Edirne:1752

1o S Sairin mesleğine ilișkin Edirne Şairlerı̈nde defterdar kaydı vardır. Diğer bilgiler için bkz.

Karagözlü, V. (2014). Hayâlî Bey, Hayalî, Mehmed Hayâlî Bey, Bekar Memi (d.903-905 ?/1497-1499 ?-ö.964/1557).

http://www.turkedebiyatiisimlersozlugu.com/index.php?sayfa=detay\&detay=6318 (e.t. 10.09.2019).

\begin{tabular}{r|l} 
Adres & $\begin{array}{l}\text { Address } \\
\text { Kırklareli Üniversitesi, Fen Edebiyat Fakültesi, Türk Dili ve Edebiyatı }\end{array}$
\end{tabular} 作 e-posta: editor@rumelide.com 1 e-mail: editor@rumelide.com 


\begin{tabular}{|l|l|l|l|}
\hline Hüsâmî & Kâtip?-Hattât?"1 & Şeyh Bâyezid & Padişah \\
\hline Hüseyin Hüsnî & Muallim & Tahsîn Bey & Kâtip \\
\hline İlmî-i Nâzik & Kadı & Tâib Hacı Muhammed & Hattât \\
\hline Kâdirî & Müderris & Talatî & Asker \\
\hline Kâmî & Müderris/Kadı & Ubeydî & Kadı \\
\hline Kemâlpaşa-zâde & Şeyhülislam & Vecdî & Hassa Harç Eminliği \\
\hline Kenzî & Bektaşî, Saz Şairi & Yakînî & Takye-dûz, Mütevellî \\
\hline Keşfî & Dîvân Kâtibi? ${ }^{12}$ & Yetîmî Ali Çelebi & Yeniçeri \\
\hline Lutfî & - & Yûsuf Demî & Asker \\
\hline Mesçizâde Sâlih Efendi & Şeyh & Yûsuf Sîne-çak & Mevlevî Şeyhi \\
\hline
\end{tabular}

Tablo I: Mecmuada yer alan şâirler

Mecmuada Edirneli olmamasına rağmen bir şekilde Edirne ile bağlantısı olan, burada yaşayan, bürokraside görev yapan şairlerin de şiirleri kaydedilmiştir. Mecmuada Edirneli olduğu bilinen şairlerin şiirlerine yapılan tahmisler ya da bu şairlerin ölümlerine ilişkin başka şairler tarafından yazılmış şiirler de kaydedilmiştir. 16. yüzyıl şairlerinden Hayâlî Bey ile ilgili olarak bir şiirin başlığında "Edirneli Hayâli Beg mevlidi Vardar neşv ü nemâsı Edirne” (v. 51) notu düşülürken; Edirne’de Halebiye, Üç Şerefeli Medresesi ve Sultan Bayezid Medreseleri'nde müderrislik/kadılık görevlerinde bulunan¹3 İbn Kemâl'in de iki gazeli mecmuaya alınmış ve "Mevlidleri Tokad ise de neşv ü nemâları Edirnedir" (v. 34) bilgisi verilmiştir.

Mecmuada ismi geçen 84 şairin 62 gazeli, 23 beyti, 15 kıtası, 11 matlaı, 5 tahmisi, 2 muhammesi, 2 müseddesi, 1 murabbaı, 4 ve 5'li bentlerden meydana gelen 2 manzum parçası vardır. Mecmuada yer alan şiirlerden hareketle 19 şairin kaynaklarda tespit edilemeyen şiirlerinin nazım şekilleri şu şekildedir;

\begin{tabular}{|c|c|c|c|c|c|}
\hline No & Şair/mahlas & Nazım şekli & No & Şair/mahlas & Nazım şekli \\
\hline 1 & Ahdî & 1 muhammes & 11 & Misâlî & 2 gazel \\
\hline 2 & Cevherî & 1 gazel/1 kita & 12 & Muinî & 1 tahmis \\
\hline 3 & Derviş Çelebi & 1 gazel & 13 & Nihânî & 1 gazel \\
\hline 4 & Fâyik & 2 beyit & 14 & Nişânî & 1 gazel \\
\hline 5 & Fazlî & 1 gazel & 15 & Nutkî & 2 gazel \\
\hline 6 & Fedâyî & 1 tahmis & 16 & Rifatî & 1 müseddes \\
\hline 7 & Hâkimî & 1 gazel & 17 & Sa'îdî & 1 gazel \\
\hline 8 & Hüsâmî & 1 gazel & 18 & Seyrî & 1 matla \\
\hline 9 & İlmî-i Nâzik & 1 gazel & 19 & Șlfâtî & 1 gazel? \\
\hline 10 & Keşfî & 1 gazel $/ 1$ tahmis & & & \\
\hline
\end{tabular}

Tablo II: Nazım Şekilleri

11 Mecmuada yer alan şiirin hangi Hüsâmî mahlaslı şaire ait olduğu tespit edilemedi. Riyâz-ı Belde-i Edirne'de Hüsâmî mahlash iki sair ve meslek bilgileri için bkz. Niyazi Adıgüzel-Rasit Gündoğdu. (2014). Ahmed Bâdî Efendi Riyâz-ı Belde-i Edirne 20. Yüzylla Kadar Osmanlı Edirne'si. Trakya Üniversitesi Yay. Edirne:1705-1706.

12 Ahmed Bâdînnin Riyâz-ı Belde-i Edirne'sinde Kesfî Bey ve Keșfí-i Diger’in ayrıntılı biyografisi için bkz.

Niyazi Adıgüzel-Rașit Gündoğdu. (2014). Ahmed Bâdî Efendi Riyâz-ı Belde-i Edirne 20. Yüzylla Kadar Osmanlı Edirne’si. Trakya Üniversitesi Yay. Edirne: $1833-1834$.

13 Saraç, Yekta. (2015). İbn Kemal (d./1469-ö./1534).

http://www.turkedebiyatiisimlersozlugu.com/index.php?sayfa=detay\&detay=6798 (e.t. 10.09.2019).

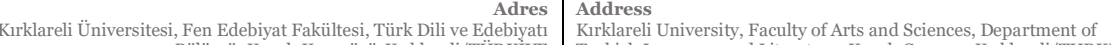
Bölümü, Kayahı Kampïsü-Kırklareli/TÜRKIYE Turkish Language and Literature, Kayalı Campus-Kırklareli/TURKEY e-posta: editor@rumelide.com 1 e-mail: editor@rumelide.com 
Kaynaklarda Edirneli oldukları belirtilen şairler yanında Edirne ile bir şekilde iltisakı bulunan şairlerin şiirlerinin de derlendiği mecmuada kaydedilen şiirlerin öncelikle şairlerin divanlarından tespiti yoluna gidilmiştir. Tabloda mahlasları belirtilen şairlerden divanları olduğu bilinenler arasında "Avnî, Emrî, Enîs Dede, Fedâyî, Hasan Sezâyî̀, Hâtemî, Hufzî, Kâmî, Kemâlpaşa-zâde, Misâlî, Mehmed Cemaleddin, Muînî, Müsellem, Nazîrâ, Nazmî, Necîb, Örfi Ağa, Rizâ, Sabrî bin İlmî-i Nâzik, Sâdlk Bey, Şevkî, Ubeydî, Yakin̂̀" vardır.14 Yukarıda mahlasları belirtilen şairlerin yayımlanmış divanları ile bir karşılaştırma yapıldığında bazı şairlerin divanlarına girmemiş şiirlerinin varlığı tespit edilmiştir. Divanlarının varlı̆̆ı bilinen ancak henüz ele geçmemiş olan şairlerin şiirlerinin tespitinde ise nazire mecmualarına ve Edirne üzerine yazılan edebî, tarihî kaynaklara başvurulmuştur. ${ }^{15}$

1.

\section{Edirneli 'Ahdī (v.6)}

Mubammes Ǵazel

mefã îlün mefā îlün mefā îlün mefã îlün

Revā mıdur saña maḥrem ola ag̉yār-ı nā-peydā

Şehā 'abd-i kadīmüñ rev idüp terk idesin şeydā

Melālet leşkeri dil kişverini eyledi yag̉mā

Ki ġam ye'cūcunüñ def'ine seddür bāde-i șahbā

Elā yā eyyühe's-sāḳī edir ke'sen vü nāvilhā

Beni ol meh şeb-i firḳatde ḳodı nice ay u yıl

Rakīibi baña ḳahr idüp ider ḳarşumda rūşen-dil

Cihānda görmedüm hergiz firāḳ-ı yārdan müşkil

Ġam-ı dildārı terk idüp ola tā mest ü lā-ya'ḳıl

Elā yā eyyühe's-sāḳi edir ke'sen vü nāvilhā

Huilāf idelden ol dilber bizümle 'ahd ü peymāna

Bu 'ālem garḳ olupdur baḥr-i eşküm içre 'ummāna

Geçüpdür rūzigārı rūzigāruñ şiddeti cāna

Ayaġı ḳaldırup nūş idelüm bu raġm-ı hūrāna

Elā yā eyyühe's-sāḳi edir ke'sen vü nāvilhā

Dilā endūh u gușṣayla yeter baḩtuñ şeb-āsā ḳıl

Ḩayāl-i la'l-i yār ile enīsüñ cām-ı hamrā ḳıl

Bu dil mir'ātını jeng-i melāletden mücellā ḳıl

İriş bu mürde cismüm bir ḳadeh mey birle ihyā ḳl

Elā yā eyyühe's-sāḳi edir ke'sen vü nāvilhā

14 Şairlerin divanlarının tespiti konusunda Edirne Şairleri’nde; “55 Edirneli şairin 'Divan' ve 3 şairin de 'Divançe' sahibi olduğu" belirtilmektedir. Bkz. Rıdvan Canım. (1995). Edirne Şairleri. Akçağ Yayınları. Ankara:16.

15 Yararlanılan kaynaklar; Osman Nuri Peremeci. (2011). Edirne Tarihi. Bellek Yayınları. Edirne; Rıdvan Canım. (1995). Edirne 20. Yüzylla Kadar Osmanlı Edirne'si. Trakya Üniversitesi Yay. Edirne. 
O mihr-i ‘ālem eyler cümle ḩalḳa ḩulḳı in‘āmın

'Acebdür 'Ahdiyā maḥrūm idersin zār u nā-kāmın

Unutsam vaḳtidür şimdengirü mülk-i fenā nāmın

Demidür nūş idem bezm-i fenā içre ecel cāmın

Elā yā eyyühe's-sāḳī edir ke'sen vü nāvilhā

2.

Tahmīs-i Edirneli Keşfi Ġazel-i Bașīrī (v.56-57)

fa ‘ilātün fa 'ilātün fa 'ilātün fa 'ilün

Sükkerīn la'lüñ gibi aġzumda ḳandim var iken

Zülf-i müşgīnüñ gibi boynumda bendim var iken

Bu dil-i dīvāne gibi derd-mendim var iken

Kande varam sāye-i serv-i bülendim var iken ${ }^{16}$

Kime ḳul olam senüñ gibi efendim var iken

Miḥnet ü derd ü gamuñla 'aşḳa el bir ideyim

Cem` idüp ‘aḳlımı ben dīvāne tedbīr ideyim

Halḳasını zülfünüün boynuma zencīr ideyim

Şerḥ-i derd-i ‘aşḳ āhir kime taḳdīr ideyim

Bir gönül adlu mușāhib derd-mendim var iken

Tir-i āhuñ ey kemān-ebrū idüp bag̉rımı hūn

Eyledi rā ḳaşları rāsı elif ḳaddimi nūn

Her ne deñlü zecr ü ḳahr eylerse bu gerdūn-ı dūn

Pend-i nāṣıḥla ne mümkün kim bulam terk-i cünūn

'Aşk pīrinden benim gūşumda pendim var iken

Olmalısın ḥüsn ile ey māh şehr içre ‘alem

'Asker-i derdüñ vücūdum mülküñi ḳldı 'adem

'Anberīn zülfüñonen ururken dil-i nālān dem

Ey perī mekr-i raḳīb-i dīv-sīretden ne gam

Hูāl-i ruhsāruñ gibi oddan sipendüm var iken

Aḳıduben firḳatüñle gözlerinden ḳanlu yaş

16 İlk bendin son iki mısral Ahmed Bâdî’nin Riyâz-ı Belde-i Edirne’sinde Edirneli Ahdînnin şiiri olarak müfredât kısmında kayitlidır.

Kande varam sāye-i serv-i bülendüm var iken

Kime kul olam senüñ gibi efendüm var iken

Bkz. Niyazi Adıgüzel-Rașit Gündoğdu. (2014). Ahmed Bâdî Efendi Riyâz-ı Belde-i Edirne 20. Yüzylla Kadar Osmanl Edirne'si. Trakya Üniversitesi Yay. Edirne:1809.

Bu șir, Mecmau'n-Nezâ’ir ve Pervâne Bey Mecmuası'nda yine Edirneli Ahdî’nin bir gazeli olarak kayıtlıdır. Karşlasturma

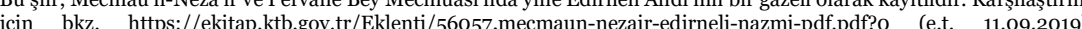
https://ekitap.ktb.gov.tr/Eklenti/55832,pervane-bey-mecmuasi-pdf.pdf?o (e.t. 11.09.2019).

Adres

Kurklareli Üniversitesi, Fen Edebivat Fakültesi, Türk Dili ve Edebivatı Krrklareli University, Faculty of Arts and Sciences, Department of

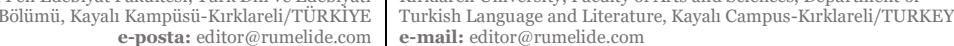


174 / RumeliDE Journal of Language and Literature Studies 2019.17 (December) Poems by poets of Edirne with reference to a macmuah / O. Kılıçarslan (pp. 167-190)

Ben ölürsem ġam degül yoluña göñlüm vire baş Sırr-ı 'aşḳı Keşfiyā 'ālemde āhum ḳıldı fāş

Gülşen-i ‘ālemde hergiz egmeyem bir sırra baş

Ey Bașīin kạ̄met-i serv-i bülendüm var iken

3.

Tah̆mīs-i Edirneli Fedāyī Ġazel-i Muḥibbīī7 (v.57-58)

fā 'ilātün fã ilātün fã 'ilātün fã ílün

Meskenet tācın urun gel ehl-i 'irfānlı̣ budur

Rāh-1 'aş̧-1 yāre düş sermest [ü] ḥayrānlık budur

Seng-i ḳahr ile mükedder olma 'irfānlık budur

Hāy u hūdan fārig ol 'ālemde sulțānlık budur

Pendini gūş eylegil mūruñ Süleymānlık budur

Ḥaz̧-1 rūḥa țālib ol ḳayd-ı bedenden yeg bilüp

Künc-i 'uzlet hāṣsll it seyr-i çemenden yeg bilüp

Kūy-1 yāri beklegil bāg̀-1 İremden yeg bilüp

Her kime ḳılsañ naẓar sen anı senden yeg bilüp

Görme kendü kendözüñ zīrā ki şeyțānlıḳ budur

Yol budur șaḳın yaman ḳaṣd eyleme yoldaşuña

İlüñ ile kim ne eylerseñ gelür hep başuña

Eyleme hergiz ḩıānet ey göñül sırdaşuña

Her ne kim saña șanursın șan anı ḳardaşuña

Fi'l-hakīka sözümi gūş it müselmānlık budur

Luṭf u iḥsān-ı Hü̉dā ile göñull şermendedür

Nūr-1 tevhīi ile zīrā gün gibi tābendedür

“Men ‘aref” sırrını añla dime kim Haḳ ḳandedür

'Āḳil iseñ istedigüñ iste yine sendedür

Ġayrı yerde ister iseñ bil ki nādānlık budur

Ey Fedāyī rāh-ı Ḥaḳdan çıḳmağıl nādān-ṣıfat

Cānuñı eyle fedā yolına gel ḳurbān-ṣıfat

'Aḳluñ̃ cem' eyle geçme bengden hayrān-ṣıfat

Nefs ḥaẓẓın ey Muhibbī virmegil ḥayvān-ṣıfat

Żabț-ı nefs it 'ārif ol 'ālemde insānlık budur

17 Fedâyî’nin Muhibbî̀ye yazdığı bu tahmise ilișkin olarak bkz. Adem Ceyhan. (2010). "Kanunînin Bir Gazelinin Yankıları" Dil ve Edebiyat Araștırmaları Dergisi-The journal of Turkish language and literatüre studies. c.1. sy.2. Yaz 2010. İstanbul.

Adres $\mid$ Address

Krrklareli Üniversitesi, Fen Edebiyat Fakültesi, Türk Dili ve Edebivatı 4 Krrklareli University, Faculty of Arts and Sciences, Department of Bölümü, Kayalı Kampusu-Kırklareli/TÜRKIYE $\quad$ Turkish Language and Literature, Kayalı Campus-Kırklareli/TURKFY e-posta: editor@rumelide.com $\quad$ e-mail: editor@rumelide.com 
4. Müseddes-i Edirneli Rif'atī Mațla'-1 Edirneli Hูayāli Beg (v.59)

mef'ūlü fã ‘ilātü mefā ‘̄iü fā ‘ilün

Nār-ı firāḳ-ı hecr ile yanı̣ degül miyem

Endūh u guușṣa çekmede fāyiḳ degül miyem

Cānā hevāña yohssa muvāfik degül miyem

'Așḳuñ yolunda ḳavline șādıḳ degül miyem

Dilberler içre ben saña 'āşı̣ degül miyem

'Uşşāḳ içinde devlete lāyık degül miyem

Nār-ı cefā ile ideli yüregim kebāb

Bezm-i belāda dīde ḳabaġım gelür şarāb

Mülk-i vücūdumu gam ile itmeden ḩarāb

'Ayş u șafādan eylemeseñ nola ictināb

Dilberler içre ben saña 'āşık degül miyem

'Uşşāḳ içinde devlete lāyık degül miyem

'Aşḳım cihānda gün gibi meşhūr eyledüñ

Hูalḳ-ı cihānı mihr ile mesrūr eyledüñ

Derd ü firāk ile beni mehcūr eyledüñ

Ben bendeñi efendi niçün dūr eyledüñ

Dilberler içre ben saña 'āşı̣ degül miyem

'Uşşāḳ içinde devlete lāyıḳ degül miyem

Ey āfitāb-ı burc-1 şeref etmeseñ vefā

Seyl-i sirişk-i dīde ider 'arż-ı mācerā

Yoḳdur felekde ḥüsnüñe ey meh-liḳā bekāā

Lāyık mıdur ki eyleyesin cānuma cefā

Dilberler içre ben saña 'āşı degül miyem

'Uşşāḳ içinde devlete lāyı̣ degül miyem

Tirr-i gamuñla eyleyeli ḳaddümi kemān

Şām u seḥerde nāle ile pür olur cihān

Derd ü belāñı çekdigüme eyleme gümān

Budur cihānda Rif'atīnüñ her sözi hemān

Dilberler içre ben saña 'āşı̣̦ degül miyem

'Uşşāḳ içinde devlete lāylk degül miyem 
176 / RumeliDE Journal of Language and Literature Studies 2019.17 (December) Poems by poets of Edirne with reference to a macmuah / O. Kılıçarslan (pp. 167-190)

\section{5 .}

Tahmīs-i Edirneli Mu‘īnì Ǵazel-i Edirneli Necātī Beg (v.59-6o)

mefā īlün mefā îlün mefā īlün mefā îlün

Yeter āvāze-i ța'n ile 'uşşāḳa șadā eyle

Gönül mir'ātini jeng-i hasedden gel cilā eyle

Dil-i bīçārenüñ derdine luṭf ile devā eyle

Gel ey zāhid temennā ḳıl baña Ḥaḳdan du‘ā eyle

Di kim dāyim anı bir dilrübāya mübtelā eyle

Gelür ș̣hḥat bulur cānā makāāmatlu eşigüñden

Varan hüuzn ile şād olur kerāmetlü eşigüñden

Baña bāg̀-ı cinān gelmez lețâfetlü eşigüñon

Efendüm devletüm varum sa'ādetlü eşigüñden

Kesilmesün 'alāḳam tek vefā itme cefā eyle

Düşüp mihrine bir māhuñ olup şūrīde vü rüsvā

Olup şevk-i ruhınla āteş-i 'aşḳa göñül şeydā

Ṭutuşup işbu nār ile giceler şem'-i cem'-āsā

Eger pervāne gibi ider iseñ yanmadan pervā

Dil-i şeydāyı yalın yüzlülerle āşinā eyle

Beḳāsı yoḳ diyü ța'n eyleyüp sevmez gülistānı

Yeter ṣog̉uḳluginnda zem ider dāyim zemistānı

Kimi cām-ı șabūh ister kimi bezm-i şebistānı

İle kimse yaramaz ey gül-i ra'nā-yı b[ū] stānī

Cefā vü cevr ü miḥnetden ne eylerseñ baña eyle

Mu 'īnī nice dem baḥr-i muḥịț-i 'aşșa țalduñsa

Nice müddet dahi ḥayret feżāsı içre kalduñsa

Vücūduñ 'āḳbet dilber yolında hāke șalduñsa

Necātī ayaġı țopraġını cān virüp alduñsa

Yüri yabanda bulmışsın gözüne tūtiyā eyle

6.

\section{Edirneli Ṣıfātī (v.24)}

\section{Mu'aşşerden müfrez beyt}

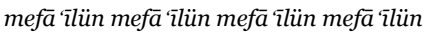

Şehā hīç görmedüm dünyāda sen teg bī-vefā yāri

Teraḥhum itmeyüp ben ‘āşıḳa eylersin āzārı 
Rakịbe yüz virüp dūr eyledüñ ben zār u nāçārı

Çün ey Yūsuf-liḳā şād eyledüñ luṭfuñla ag̉yārı

Bu dil Ya'ḳūbunuñ dünyāda oldı ag̉lamaḳ kārı Şikāyet eylerem Mevlāya senden terk it aġyārı

Ne zuulm itdüñse dīvān-ı Hüuāda müşkil efkārı

Görürsem rūz-ı mahșer sen vefāsız yār-ı gaddārı

Ḳılam feryād ile çāk-i girībān eyleyüp zārī

Senüñle mācerāmız fașl ide tā Ḥażret-i Bārī

Edirneli Luṭfi (v.25)

mefā ‘ilün fe ‘ilātün mefā ‘ilün fe ‘ilün

Fiḡānla zahmm-hูor-1 tìğ-1 şahṣ̣̂-ı nādānam

Hemīşe çāk şüd dest ye's [ü] ḥarmānam

Leb-i ümīd dem-i teşnegī ile șad çāk

Kenār-ı cūy-ı emelde sifāl-i reyhānam

Sezā-yı kūşe-i destār berg-i sebzüm yok

Meger ki yoḳ yire bāğ-ı fenāda nālānam

Fuṣūl-i erba‘ada bir ḳabāya ḳāni` olup

Miŝāl-i serv bu gülșende çìde-dāmānam

Egerçi țūṭ̂i-i mu ciz-nümā-yı naẓmum līk

Baḳılsa āyīne-veş 'ibret ile ḥayrānam

8.

Edirneli Mis̄ālī Beg (v.25)

fe ‘ilātün fe ilātün fe 'ilün

Ruhı cennet kadi țūbāsın sen

Nice țūbā dahi a ‘āsın sen

Āh-1 'uşşāḳ ile ey kūy-ı ḥabīb

Örtüli Ka‘be-yi ‘ulyāsın sen 
178 / RumeliDE Journal of Language and Literature Studies 2019.17 (December) Poems by poets of Edirne with reference to a macmuah / O. Kılıçarslan (pp. 167-190)

\author{
Ay başında görinürsin bir gün \\ Kaş̧ları ġurre-i garrāsın sen \\ Yaḳmag̉a diller ararsın şāhum \\ Nola dirlerse dil-ārāsın sen \\ Ey Miŝâlī nice toz ḳonduralar \\ Tab`-1 mir'āt-ı mücellāsın sen
}

9.

Edirneli Miŝālī Beg18 (v.26)

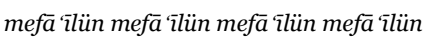

Felekde kimseye baş egmezin ey ḳaşları garrā

Kanā‘at itmek olur bir dilim nāna hilāl-āsā

Düri dendānuña siḥr ile teşbīh eylemiş gavvāṣ

'Aceb mi yüzine țuzlı șular ḳoysa anuñ deryā

Halāṣ olmaḳ dilerseñ sākiyā girdāb-ı mị̣netden

Kenār-1 'işrete dāyim çekilsün zevraḳ-ı șahbā

Yanup yaḳılma ey dil kimseye ol mihr-i enverden

Ne o[d]lar ḳalġıdur pervāneye gör şem‘-i bezm-ārā

Eger sen dahi bir ebrū-kemānuñ cevrini çekseñ

Miŝālīnüñ bilürdüñ çekdigin ey kaş̧ları țugrāā

10.

Derviş Çelebi Edirnevī (v.27)

mef'ūlü fã ‘ilātü mefā 'ìlü fã 'ilün

Bezm-i cihānda itmez iken nūș-ı cām Cem

Sāgar șunardı destüme bir müstedām dem

Emvāc-ı baḥr ḳulzüm-i eşkümden itdi ḩavf

Yüz yire sürdi eyledi çün iltiyām yem

18 Misâlî Bey'in bu gazelinin matla beyti Ahmed Badi'nin Riyâz-ı Belde-i Edirne'sinde müfredat kısmında kayıtlıdır. Bkz. Niyazi Adıgüzel-Raşit Gündoğdu. (2014). Ahmed Bâdî Efendi Riyâz-ı Belde-i Edirne 20. Yüzylla Kadar Osmanlı Edirne'si. Trakya Üniversitesi Yay. Edirne: 1844 . 
Gül saña nice beñzeye kim yoḳdur anda bū Sünbül gülāle serv-ḳad ü gonçe-fām fem

Düşdük hadeng-i gaamzeñ ile dām-ı zülfüñe Nahçīr-i hān u șayd-ı dil-i müstehām hem

Sen gayrılarla demde șafāda revā mıdur Dervisşüñ aḳsa böyle gözünden müdām dem

11.

Nişānī Meḥmed Paşa Edirnevī (v.3o)

Üsküfçü Ḩı̇ır Mahallesinde medfūndur fã 'ilātün fã 'ilātün fã 'ilātün fã 'ilün

‘Āşı̣uz biz ‘āşı̣uñ ḳadrin bilen yār isterüz

Baḳmazuz bī-mihre bir yār-ı vefādār isterüz

Bir sipāhī dilberinüñ gamzesi mecrūḥıyuz

Hูasteyüz tāb-1 teb-i hicrāna tīmār isterüz

Ol gül-endāma didüm 'uşşāḳı zār itmek neden

Güldi didi biz gülüz bülbülleri zār isterüz

Hูāl ü ḩațt u zülf sever iş ḳabūl itmez gönüul

Nakșa meftūn olmazuz bir sāde dildār isterüz

Reng ü būya meylümüz yoḳdur Nișānī gerçi kim

Lāle-ruhlarla yine rengīn eș‘ār isterüz

12.

Edirneli Keşfī (v.31)

fã 'ilātün fã 'ilātün fã 'ilātün fã 'ilün

Ey sehāvet gülşeninde menba'-1 luṭf u vefā

Hākipāyüñudur cihānda var ise ger kīmiyā

Gül vücūduñdur mu'azzez meclis-i muhtārda

Çün dilüñden muḥkem oldu rāh-ı şer‘-i Mușțafā

Bahrr-i żilletden çıkup ten 'īme erişmiş durur

Lutfunuñ bir kațresi ile olanlar āșinā 
180 / RumeliDE Journal of Language and Literature Studies 2019.17 (December)

Poems by poets of Edirne with reference to a macmuah / O. Kilıçarslan (pp. 167-190)

Dest-i gamdan Keşfinüñ ḳurtar yaḳasın ḳll kerem

Dāmenüñe geldi düşdi şimdi ey kān-ı sehā

Yüz urup ihlāṣ ile Keşfi fakīrüñ tuhfesi

Ḩażretiñüze şehā leyl ü nehār olsun du‘ā

Hูașmınuñ yüzi anuñ ayag่ına düşsün müdām

Devletüñ pāyende vü ‘ömrüñ mezīd olsun şehā

$13 .{ }^{19}(\mathrm{v} \cdot 32)$

mefāi îlün mefā ‘̄iün mefā îlün mefā ‘ilün

Maḥabbet etmege bir dilber-i ‘ayyār arar göñüm

Binā-yı 'aşḳa bünyād urmaġa mi'mār arar göñlüm

Bu bāğ-1'ālem-ārāda egerçi ġonçe-lebler çok

Nigārā pāk-dāmān bir gül-i bī-hnār arar göñlüm

Kenār-1 sāye vuṣlatda anuñla hoş geçem diyü

Kad-i bālā güzel bir serv-i ḩoş-reftār arar göñlüm

Mu'atțar olmag̉a bir zülf-i 'anber-bū diler göñlüm

Perīşān olmag̉a bir țurre-i țarrār arar göñulüm

Bugün ey Cevherī bir ġonçe-i ḩandānuñ 'aşḳına

Demādem girye vü zār olmaga gülzār arar göñlüm

14.

Edirneli ‘'̇lmī Nāzik (v.33)

fe ‘ilātün fe iilātün fe ‘ilātün fe ‘ilün

Bu cihānuñ be yüri yārına ag̉yārına yuf

Ag̉ladup yüze gülen hārına gülzārına yuf

Dahi biñ nāz ile bu şimdiki mahbūblaruñ

‘Āşı̣a eyledigi ‘ahdine iḳrārına yuf

\footnotetext{
19 Mecmuada gazelin başında "Cevherî Karaferyeli İbn-i Yemîn Çelebi imiş âhiren tahkîk olundı Harrât-zâde Cevrî imiş" notu düssülmüstür. Bu düzeltme, mecmuada "Edirneli Harrât-zâde Cevherî” başlı̆̆ı silinerek şairin Edirneli olmadığın açıklamak amacıyla kaydedilmiş̦tir. Şair hakkında bkz.

Kaplan, Y. (2014). Cevherî, İbn-i Yemîn (d.?/?-ö.990/999?/1582/159o?).

http://www.turkedebiyatiisimlersozlugu.com/index.php?sayfa=detay\&detay=1848 (e.t. 22.10.2019).

Adres

Kurklareli Üniversitesi, Fen Edebivat Fakültesi, Türk Dili ve Edebivat $\quad$ Krrklareli University, Faculty of Arts and Sciences, Department of ( e-posta: editor@rumelide.com $\quad$ e-mail: editor@rumelide.com
} 
Pey-i halvetde çıkup işbu zamān șūfileri

Halḳdan ya'nī ki șaḳladığı esrārına yuf

Dahi ba‘żı cühelānuñ ẓurefādan geçinüp

Ehl-i 'irfān șanıcı ‘āifi ü 'ayyārına yuf

‘İlmiyā sende șaḳın oḳunıcaḳ bu gazelüñ

Diyeler buncılayın șā'irüñ eş‘ārına yuf

15.

Edirneli Fażlī (v.33)

fā 'ilātün fā ílātün fā 'ilātün fā 'ilün

Kāş yüz biñ başum olsa saña ḳurbān eylesem

Her birin pāy-ı seg-i kūyuñda galțān eylesem

Kāş yüz biñ dīdem olsa tende cānā her birin

Dürr-i dendānuñ gamında ‘ayn-ı ‘ummān eylesem

Kāş yüz biñ sīnem olsa 'arṣa-i ālāmda

Her birini gamzeñüñ tīrine kalḳan eylesem

Kāş yüz biñ cismüm olsa 'aşk ile büryān idüp

İtlerüñi her gice külbemde mihmān eylesem

Kāş yüz biñ 'aḳlum olsa Fażlī-i dīvāneyem

Her gice efkār-ı zülfüñle perīșān eylesem

16.

Edirneli Ḥüsāmī (v.35)

fe 'ilātün fe ilātün fe 'ilātün fe ilün

Girse rakșa țaġıdup kākülüni ol dilber

Cān atar üstüne 'ușşāḳ-ı perīṣān-diller

Ne kerāmet durur āyā ki o ‘'̄sā dehenüñ

Bir kelāmı nice biñ mürdeyi ihyyā eyler

Sīnemi delse okuñ zerre kadar incinmez

Ġamını yā kașuñuñ her ne kadar olsa çeker 
182 / RumeliDE Journal of Language and Literature Studies 2019.17 (December) Poems by poets of Edirne with reference to a macmuah / O. Kılıçarslan (pp. 167-190)

Nāz ile gülşene geldi görüñ ol gonçe-dehen

Erişüp şāhid-i nevrūz açıldı güller

Çünkü her vech ile bir lāyıḳ-ı ị̣sānuñdur

Ḳıl Ḥüsāmī ḳuluñu luṭf-ı vefāya maẓhar

17.

\section{Edirneli Sa'īdī (v.35)}

mefā 'ìlün mefā î̀ün mefā īlün mefā ìlün

Kerem ḳll bendeñe kān-ı keremsin yā resūlullāh

Ki sen hulḳ-ı 'aẓīm ile 'alemsin yā resūlullāh

Senüñ cūyende-i elțāfuñ olmuş așfiyā zīrā

Şefā'atle ḳamudan muḥteremsin yā resūlullāh

Delīl ol ḳılmasun șaḥrā-yı ġamda bu dil-i şeydã

Cihān-ı mürşid-i rāh-ı ḳademsin yā resūlullāh

Halāṣ eyle girībān-ı dili dest-i nedāmetden

Cemī'-i kā'ināta sen ḥakemsin yā resūlullāh

Bu üftāde Sa‘īdī vāṣıll-ı evc-i ma‘ārif ḳl

'Ușāt-ı ümmete 'ālī-himemsin yā resūlullāh

18.

Edineli Ḥākimī (v.35)

fe 'ilātün fe 'ilātün fe 'ilātün fe ‘ilün

Māh-ı nev gàm şüdedür heybet-i ebrūsından

Çākdür sīne-i meh āyet-i pehlūsından

Feyż alur müşk-i Hoten țurre-i hoş-būsından

Mevc urur "1țr-1 hevā kākül-i şebbūsından

Mest olur 'aḳl-ı muṣavver dahi eylerse nigāh

Sāḥir-i fitnesinüñ naẓra-i āhūsından

Gösterür mu'cize-i hüsn-i şikāf-ı ebrū

Resm-i şakk-1 kameri cebhe-i mehrūsından 
Ḥākimā būs-ı leb-i yāri țaleb-kār olsam

Harf-i red zāhir olur la'l-i sühan-gūsından

19.

Nihānī-i Edirnevī (v.36)

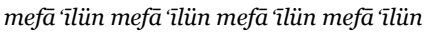

Cihānuñ varlığı cümle dilā hāb u hayāl ancak

Hakịkat gözleseñ belki füsūn u mekr ü āl ancak

Müsāfir-ḩānedür dünyā țurur ma'nīde eskiden

Gelen bunda gider țurmaz maḥall-i intiḳāl ancaḳ

Riyā vü zerḳ ile zāhid dilersin dost dīdārın

Hey ol efkār-ı fāsiddür bular fikr-i muhāl ancak

Eger 'ibret gözi ile naẓar itseñ siyeh ḩāke

Görinen çeşm ü ebrūdur veyā zülf ile ḩāl ancak

Nihānī kendü tașvīrin meger kim yine yār etmiş

'Aceb şūrīde olmuşdur şikeste-beste hāal ancak

20.

Edirneli Nuṭ̣̂ī Ḳaraḳaş-zāde Pīr Meḥmed Çelebi (v.63)

mef'ūlü mefā 'ìlü mefā î̀lü fe ‘ūlün

Bir nice zamān oldı ki ol dilber-i ra'nā

Huūrşìd gibi gün yüzin 'arż itmeyüp aṣlā

‘Āşıkları hicrān odına yaḳdı o mehrū

Hīç žerrece bilmez ne çeker 'āşıḳ-1 şeydā

Makssūu nedür pādișehüm bunca sitemden

Oldum ġam-ı 'aş̧̣uñ ile ‘ālemlere rüsvā

Bir būse içün varumı hep yoluña virdüm

İnșāf eŝeri hāạtırıña gelmedi ḳaț ā

Aġyār ile hem-meclis olup bādeler içme

Nuṭ̣̂̄ o civānuñ işine ḥayf u dirīgāā 
184 / RumeliDE Journal of Language and Literature Studies 2019.17 (December) Poems by poets of Edirne with reference to a macmuah / O. Kılıçarslan (pp. 167-190)

21.

Edirneli Nuṭ̣̄ị Ḳaraḳaş-zāde Pīr Muḥammed Çelebi (v.62)

fe ilātün fe ilātün fe ilātün fe iliün

Ben senüñ çāh-ı zenahdānına ḳurbān olayum

Yüz sürüp pāyuña dāmānuña ḳurbān olayum

Nice başdan çıkarır ādemi ol kāküller

Vaṣf olunmaz ruh-ı rahşānuña ḳurbān olayum

Rūz u şeb vird-i zebān oldı baña bu mıșra

Seḥer ol ḳadd-i hırāmānuña ḳurbān olayum

Kižb ider pādişehüm saña rakịib aldanma

Dün dimiș ḩançer-i bürrānuña ḳurbān olayum

Mest olup ḥālini 'arż eyledi yāra Nuṭḳī

Didi kim țarz-ı levendāneñe ḳurbān olayum

22.

Cevherīîn $^{20}$ (v.28)

Tārīhn-i Vefāt-ı Sulțān Süleymān

mefā îlün mefā īlün mefā îlün mefā ‘ulün

Cihān-ı bī-bekāandan rūḥ-ı pāki rı̣̣let itdükde

Dimiş sulțān Süleymān pend idüp og̉ı Selīm H̦āna

Șaḳın mag̉rūr olup bu devlet-i dünyāya aldanma

Ne Efrīdūna kalmıșdur bu ne Zāl ü Nerīmāna

Selīmüm 'adl ü dād it saña bizden bu yeter tārīh

Bilürsin ḳalmadı bāḳi cihān mülki Süleymāna

23.

Edirneli Fāyiḳ Efendi (v.53)

fā 'ilātün fā ilātün fã 'ilātün fã ìiün

Her zamān yoḳdur dehānı diyü yārüñ söyledüm

‘Ömrümüñ varın 'ademde ḥayf żāyi' eyledüm

20 Cevherî̀ye ait bu tarihin başlı̆̆ “Edirneli Harrât-zâde Cevherî” kaydedilmiş, devamına bir düzeltme notu olarak "Edirneli değil imis" ibaresi düsülmüsșür.

Adres

Krklareli Üniversitesi, Fen Edebiyat Fakültesi, Türk Dili ve Edebiyatı $\quad$ Kırklareli University, Faculty of Arts and Sciences, Department of Bölümü, Kayahı Kampusu-Kırklareli/TURKIYE e-posta: editor@rumelide.com $\quad$ e-mail: editor@rumelide.com 
Dest-res oldum egerçi gevher-i makșūdına

Bir iki kerre yem-i āfāḳı ammā boyladum

24 .

Edirneli ‘Ömer Seyrī Efendi (v.73)

mef'ūlü mefā ìlü mefā ìlü fe 'ūlün

Āvāre dili bend idicek zülfine cānān

‘Āşı̣ın ider sāye gibi ḩāk ile yeksān

\section{Sonuç}

Gelenek içinde belli kaideler esas alınarak mürettep bir şekle sokulan divanların bizzat şairinin kontrol ettiği müellif nüshalarında dahi bazı eklemeler/çıkarmalar görülebilmektedir. Bu durum divan sahibi şairin bazı şiirlerini çıkardığını, bazılarını ise tashih ettiğini göstermektedir. Müellifin elinden geçmiş ve kontrol edilmiş nüshalar yanında şairin tertip edildiğini görmediği örnekler de mevcuttur. Özellikle hayatta iken divanını bir araya getirememiş şairlerin şiirleri dönemindeki mecmualarda dağınık biçimde kaydedilmiştir. Bazı mecmualardan hareketle divanları neşredilen veya mecmualarda bir divan yahut divançe teşkil edecek kadar şiiri bulunan şairlere de rastlanmaktadır.

Özellikle tenkitli metin oluşturmada başvurulan mecmualar farklı özellikler gösterebilmektedir. Bu mecmualardan bir kısmı içinde şiirleri kaydedilen şairler belli bir yüzyıla kadar gelebilmektedir. Bu tarz mecmualar yanında ortak özellik gösteren mecmualar da derlenmiştir. Son dönemde derlenen mecmualarda kaydedilen şiirlerin şairlerine ilişkin farklı kaynaklardan bilgilerin de kullanıldı̆̆ görülmektedir. Edirne Selimiye Yazma Eser Kütüphanesi’nde 22 Sel 2299 numara ile kayıtlı mecmua da bu özellikleri içeren bir mecmua olarak dikkat çekmektedir. Mecmuada Edirne veya Edirneli ibareleriyle tanıtılan şairlerin bir kısmı diğer edebî kaynaklarda da geçmektedir. Bunun yanında tarihî olarak Edirneli olmadığı bilinen bazı şairlere de Edirne ile olan münasebeti sebebiyle aynı isimlendirmeler yapılmıştır. Mecmuaya sonradan eklendiği anlaşılan şiirlerin ortak özelliği, şairlerinin Edirneli veya Edirne ile olan ilişkisidir. Mecmuanın tamamında 84 şaire ait farklı nazım şekilleriyle yazılmış şiirler vardır. Çŏ̆u, şairlerin mürettep divanlarında bulunan bu şiirlerin bir kısmına ise ne divanlarında ne de Edirne ve Edirneli şairleri anlatan biyografik kaynaklarda tesadüf edil(e)memiştir. Bu çalışmada Edirneli şairlerin şiirlerinin derlendiği bir mecmua esas alınarak bu şairlerin kaynaklarda yer almayan şiirleri tespit edilmeye çalışılmıştır.

\section{Kaynakça}

Aksoyak, İ. H. (2014). Türk Edebiyatı İsimler Sözlüğü (TEIS-I).

http://www.turkedebiyatiisimlersozlugu.com/index.php?sayfa=detay\&detay=3591

Aksoyak, İ. H. (2014). Türk Edebiyatı İsimler Sözlüğü (TEIS-I).

http://www.turkedebiyatiisimlersozlugu.com/index.php?sayfa=detay\&detay=1463

Ayverdi, İ. (2005). Asırlar Boyu Târihî Seyri İçinde Misalli Büyük Türkçe Sözlük. İstanbul: Kubbealtı Neşriyâtı.

Canım, R. (1995). Edirne Şairleri. Ankara : Akçă̆

Ceyhan. A. (2010). “Kanunînin Bir Gazelinin Yankzları”. Dil ve Edebiyat Araştırmaları Dergisi-The journal of Turkish language and literatüre studies. c.1. sy.2. Yaz 2010. İstanbul.

Erkan, A. (2012). El-Beyan Arapça-Türkçe Büyük Sözlük. İstanbul: Yasin 
186 / RumeliDE Journal of Language and Literature Studies 2019.17 (December)

Poems by poets of Edirne with reference to a macmuah / O. Kilıçarslan (pp. 167-190)

Glynaş, K. A. (2017). Ankara: Kültür ve Turizm Bakanlığı.

https://ekitap.ktb.gov.tr/Eklenti/55832,pervane-bey-mecmuasi-pdf.pdf?o

Kaplan, Y. (2014). Türk Edebiyatı İsimler Sözlüğü (TEIS-I)

http://www.turkedebiyatiisimlersozlugu.com/index.php?sayfa=detay\&detay $=1848$

Karagözlü, V. (2014). Türk Edebiyatı İsimler Sözlüğü (TEIS-I).

http://www.turkedebiyatiisimlersozlugu.com/index.php?sayfa=detay\&detay $=6318$

Köksal, M. F. (2006). Sana Benzer Güzel Olmaz. Divan Şiirinde Nazire. Akçağ Yayınları. Ankara.

Köksal, M. F. (2013). Türk Edebiyatı İsimler Sözlüğü (TEIS-I).

http://www.turkedebiyatiisimlersozlugu.com/index.php?sayfa=detay\&detay=327

Köksal, M. F. (2017). Ankara: Kültür ve Turizm Bakanlı̆̆ı.

https://ekitap.ktb.gov.tr/Eklenti/56057,mecmaun-nezair-edirneli-nazmi-pdf.pdf?o

Mecmua-i Eş'ar. Edirne Selimiye Yazma Eser Kütüphanesi. 22 Sel 2299

Niyazi Adıgüzel-Raşit Gündoğdu. (2014). Ahmed Bâdî Efendi Riyâz-ı Belde-i Edirne 20. Yüzyıla Kadar Osmanlı Edirne'si. Edirne: Trakya Üniversitesi.

Peremeci, O. N. (2011). Edirne Tarihi. Edirne: Bellek.

Saraç, M. A. Y. (2015). Türk Edebiyatı İsimler Sözlüğü (TEIS-I).

http://www.turkedebiyatiisimlersozlugu.com/index.php?sayfa $=$ detay $\&$ detay $=6798$

Sunal, A. (2014). Sâdık Dîvânı (İnceleme-Metin). Uludağ Üniversitesi SBE. Doktora Tezi. Bursa.

Tanyıldız, A. (2014). Türk Edebiyatı İsimler Sözlüğü(TEIS-I).

http://www.turkedebiyatiisimlersozlugu.com/index.php? sayfa $=$ detay\&detay $=4826$ 


\section{Örnek Metinler}

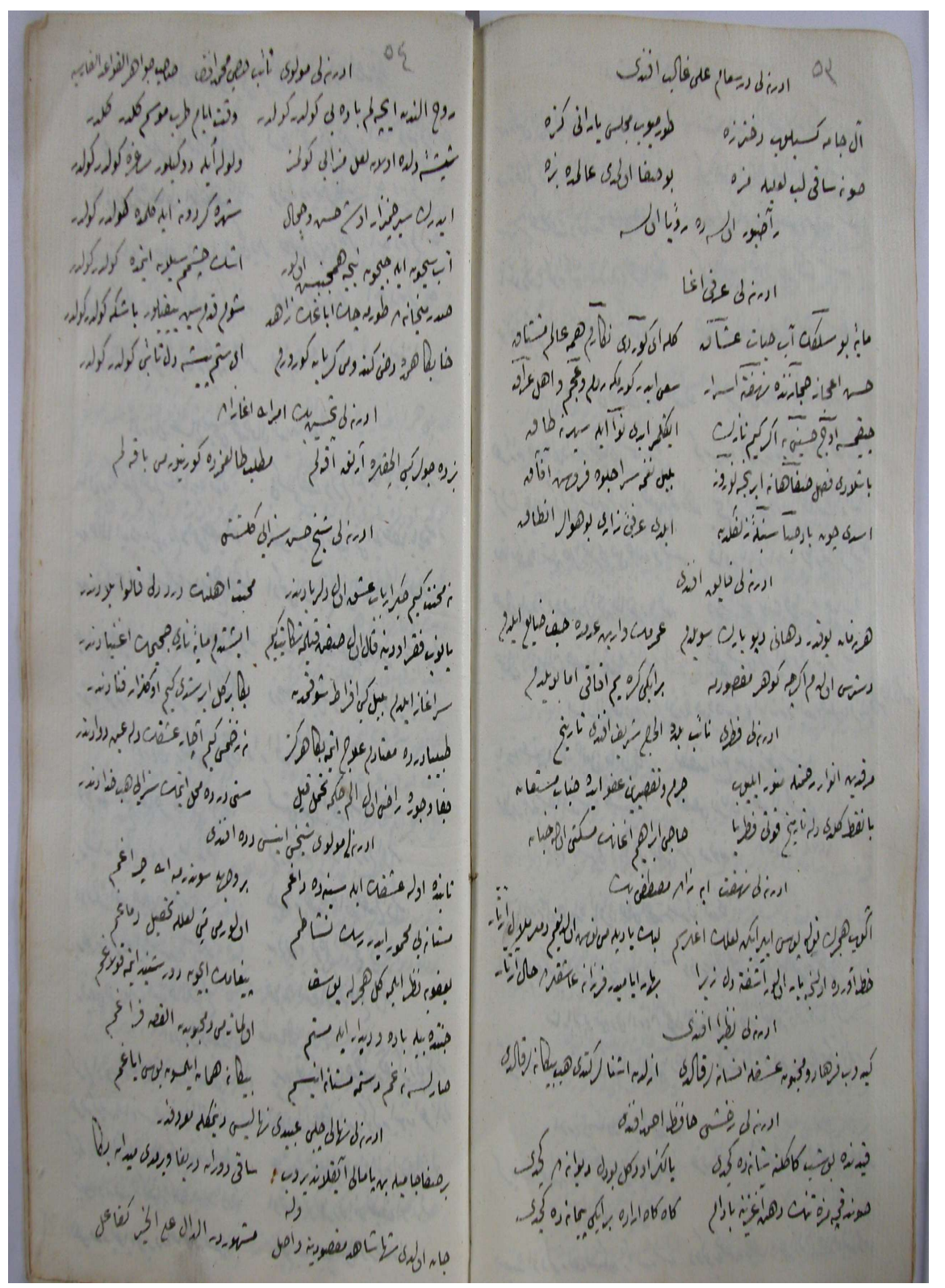
\begin{tabular}{r|l} 
Adres & Address \\
Kurklareli Üniversitesi, Fen Edebiyat Fakültesi, Türk Dili ve Edebiyatı & Krrklareli University, Faculty of Arts and Sciences, Department of \\
Bölümü, Kayalı Kampüsü-Krrklareli/TÜRKIYY & Turkish Language and Literature, Kayalı Campus-Kurklareli/TURKEY \\
e-posta: editor@rumelide.com & e-mail: editor@rumelide.com
\end{tabular} 
188 / RumeliDE Journal of Language and Literature Studies 2019.17 (December)

Poems by poets of Edirne with reference to a macmuah / O. Kilıçarslan (pp. 167-190)

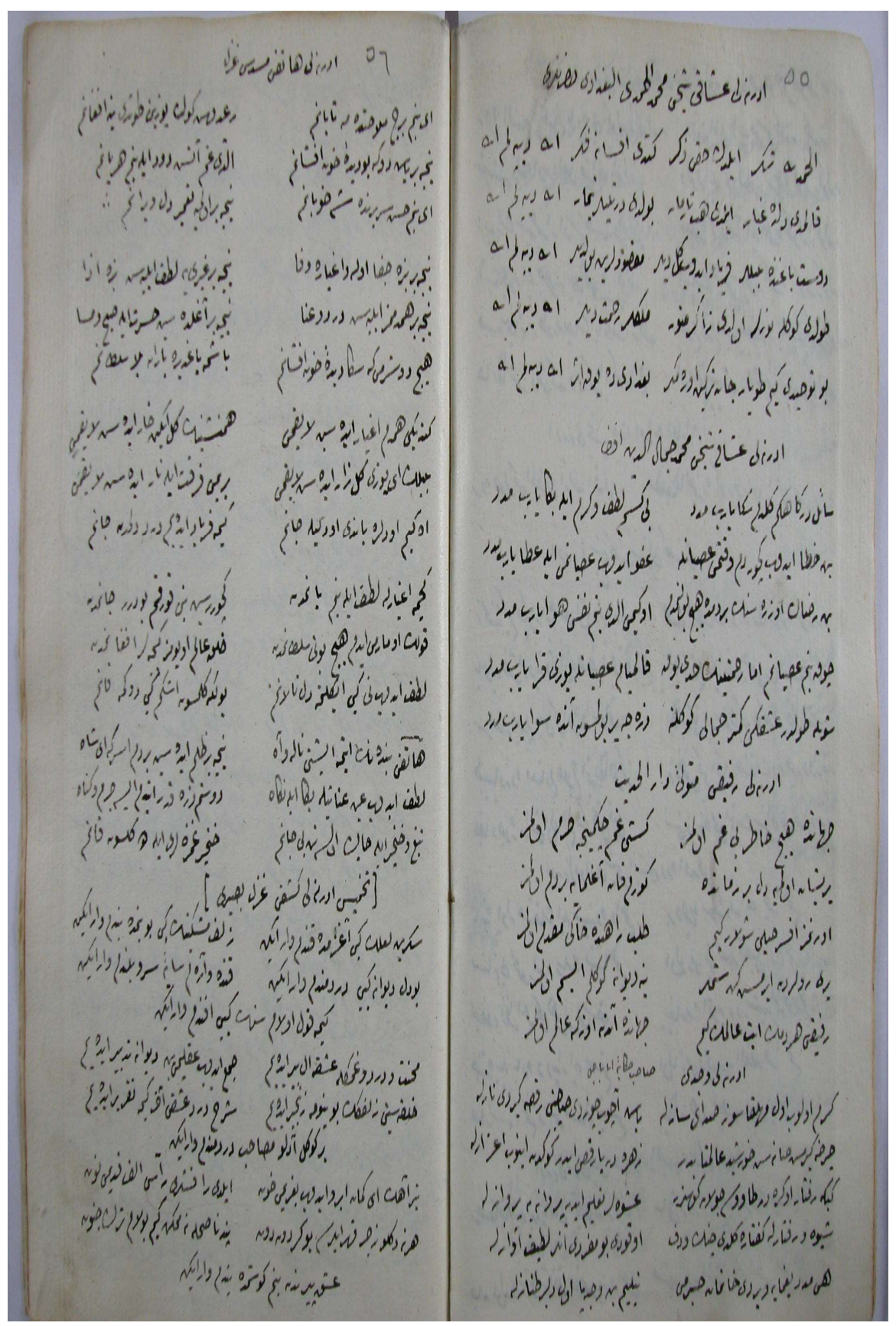

\begin{tabular}{r|l} 
Adres & Address \\
Kırklareli Üniversitesi, Fen Edebiyat Fakültesi, Türk Dili ve Edebiyatı & Kirklareli University, Faculty of Arts and Sciences, Department of
\end{tabular}

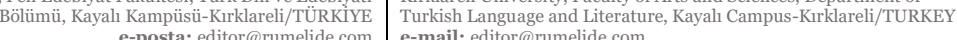




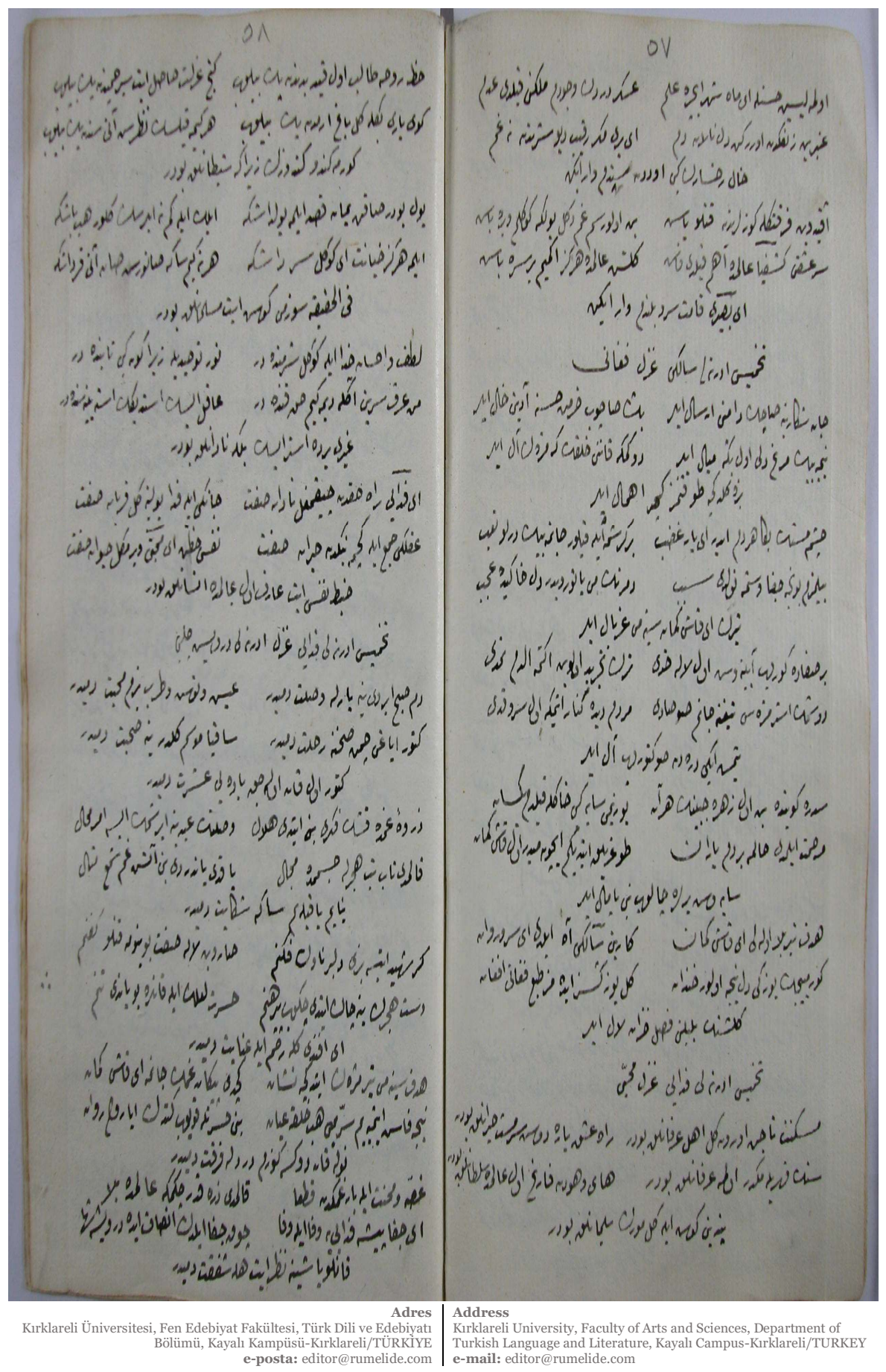




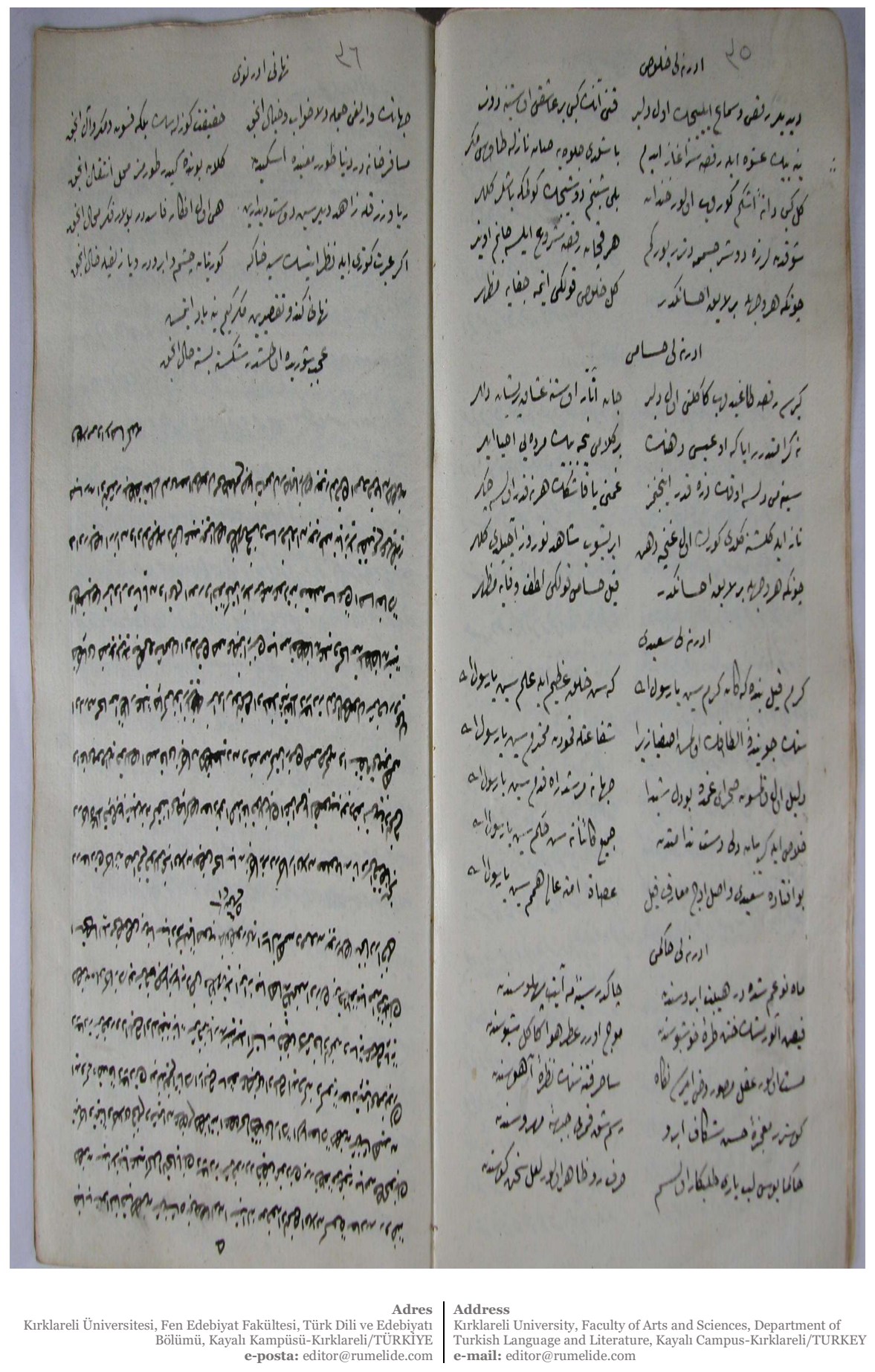

